\title{
The chemotherapeutic potential of Terminalia ferdinandiana: Phytochemistry and bioactivity
}

\author{
S. Mohanty, Ian E. Cock \\ Biomolecular and Physical Sciences, Environmental Future Centre, Nathan Campus, Griffith University, Nathan Brisbane, Queensland, Australia \\ Submitted: 25-03-2011 \\ Revised: 25-03-2011 \\ Published: 08-05-2012
}

\section{A B S TR A C T}

Plants contain a myriad of natural compounds which exhibit important bioactive properties. These compounds may provide alternatives to current medications and afford a significant avenue for new drug discovery. Despite this, little information is available in the literature regarding native Australian plants and their potential for medicinal and industrial uses. Recent studies have reported Terminalia ferdinandiana to be an extremely good source of antioxidants. Indeed, T. ferdinandiana has been reported to have ascorbic acid levels per gram of fruit more than 900 times higher than blueberries. T. ferdinandiana also has high levels of a variety of other antioxidants, including phenolic compounds and anthocyanins. Antioxidants have been associated with the prevention of cancer, cardiovascular diseases, and neurological degenerative disorders. They are also linked with antidiabetic bioactivities and have been associated with the reduction of obesity. Antioxidants can directly scavenge free radicals, protecting cells against oxidative stress-related damage to proteins, lipids, and nucleic acids. Therefore, $T$. ferdinandiana has potential in the treatment of a variety of diseases and disorders and its potential bioactivities warrant further investigation.

Key words: Australian medicinal plants, antioxidants, gubinge, Kakadu plum, Terminalia ferdinandiana, vitamin C

\section{INTRODUCTION}

Approximately $25 \%$ of all prescription drugs currently in use are originally derived from plants. ${ }^{[1]}$ Furthermore, approximately $75 \%$ of new anticancer drugs marketed between 1981 and 2006 are derived from plant compounds. ${ }^{[1]}$ Despite this, only $10 \%$ of the estimated 250,000 species worldwide have been screened for any bioactivities. Plants produce a variety of biologically active compounds which exhibit an array of properties. ${ }^{[2]}$ The study of plant pharmacognosy could lead to the discovery of commercially and/or therapeutically useful phytochemicals possessing a diverse range of activities. As a result of its geographic isolation, Australia is home to a large variety of unique and distinct flora not found elsewhere in the world. Due to the harsh conditions

Address for correspondence:

Dr. Ian Cock, Biomolecular and Biomedical Sciences,

Griffith University, Nathan Campus, 170 Kessels Road,

Nathan, Queensland 4111, Australia.

E-mail: I.Cock@griffith.edu.au

\begin{tabular}{|l|l|}
\hline \multicolumn{2}{|c|}{ Access this article online } \\
\hline Quick Response Code: & Website: \\
\hline & www.phcogrev.com \\
\cline { 2 - 2 } & \\
\hline
\end{tabular}

seen in many parts of Australia, plants have developed unique survival methods specific to the environmental conditions they inhabit and may hold the key to the treatment of many diseases and medical conditions. Traditional Aboriginal knowledge of plants as therapeutics is disappearing as the Aboriginal culture merges into main stream society and the passing of oral traditions between each generation diminishes. Given the diverse nature of the flora present and the diminishing traditional knowledge, Australian plants remain relatively unstudied and it is surprising that more research has not been done into their potential.

There are about 250 species of the genus Terminalia (family of Combretacea) occurring in various tropical countries ${ }^{[3]}$ of which 28 species or subspecies grow in Australia. ${ }^{[4]}$ Terminalia ferdinandiana is an Australian native plant which is commonly known as Kakadu plum gubinge, billy goat plum, or salty plum. ${ }^{[5]}$ T. ferdinandiana is a small to moderately sized semideciduous tree, which occurs mainly in the tropical grassland of the Northern Territory, Queensland, and northwestern parts of Western Australia. ${ }^{[6]}$ T. ferdinandiana flowers at the end of the dry season (September-November) and has fruits from middle of the wet season (January-June) to the early part of dry season, depending on its location. The fruits are smooth-skinned, yellow-green in color, about $1.5-2 \mathrm{~cm}$ long and ovoid in shape, often with a short beak at the tip. ${ }^{[7]} T$. ferdinandiana is sometimes mistaken for and thought to be closely related to $T$. carpentariae, $T$. badleyana, and T. latipes. ${ }^{[4,7,8]}$ Sometimes it is also incorrectly identified as with T. prostrata. ${ }^{\left[{ }^{[9]}\right.}$ 
As with many of the other Australian Terminalia species, $T$. ferdinandiana fruits and seeds have historical uses in the Aboriginal diet and as a medicinal plant. ${ }^{[10]}$ Australian Aborigines ate the fruit directly, used it to make a refreshing drink and also used it to make edible jelly and gum. ${ }^{[3]}$ Recently, T. ferdinandiana fruits have been reported as the richest naturally occurring source of vitamin $\mathrm{C}$ worldwide. ${ }^{[11,12]}$

\section{PHYTOCHEMISTRY OF T. FERDINANDIANA AND POTENTIAL MEDICINAL BENEFITS}

Epidemiological studies have shown that a high uptake of fruits/vegetables is associated with lower risk of developing chronic diseases. ${ }^{[13]}$ High antioxidant levels have previously been demonstrated to act as preventative effects against the development of degenerative diseases such as cancer, ${ }^{[14]}$ cardiovascular diseases ${ }^{[15]}$ neural degeneration, ${ }^{[16]}$ diabetes, and obesity. ${ }^{[17]}$ Phenolic compounds are generally known as strong antioxidants. ${ }^{[18]}$ Their primary action is the protection of cell constituents against oxidative damage through the scavenging of free radicals, thereby averting their deleterious effects on nucleic acids, proteins, and lipids in cells. ${ }^{[18]}$ Phenolics interact directly with receptors or enzymes involved in signal transduction, ${ }^{[19]}$ clearly indicating that they play a specific role in human physiology. Common plant phenolic compounds include flavonoids, tannins, anthocyanins, and gallic acid.

Previous studies on related species of the genus Terminalia have examined bioactivities including antibacterial, ${ }^{[20]}$ cardiovascularity, and anti-inflammatory activities. ${ }^{[21]}$ One study has focused on the potential of Terminalia arjuna for alleviating angina and other cardiovascular conditions. ${ }^{[22]}$ The stem bark of T. arjuna contains a myriad of phytochemicals including glycosides, large quantities of flavonoids, tannins, and numerous minerals. Flavonoids in particular have been demonstrated to exert antioxidant, antiinflammatory, and blood lipid lowering effects. ${ }^{[23]}$ Furthermore, glycosides are useful as cardiotonic agents, making $T$. arjuna popular amongst currently used medicinal plants in the Indian system medicines. ${ }^{[24]}$

While studies into the bioactivities of T. ferdinandiana are lacking, a recent report has described its fruits as richest sources of vitamin $\mathrm{C}$ [Figure 1a] of any plant in the world. ${ }^{[12]}$ The content of vitamin $C$ varies from $3.5 \%$ to $5.5 \%$ of recorded wet weight ${ }^{[23,24]}$ in comparison to orange, grapefruit, and lime containing only approximately $0.5 \%{ }^{[25]}$ Due to its high vitamin C levels, the primary use of $T$. ferdinandiana fruit is for production of vitamin $\mathrm{C}$ in health food, cosmetic, and pharmaceutical industries. However, T. ferdinandiana fruit also contains many other compounds which also contribute to its high antioxidant activity. ${ }^{[1,12]}$ While many of these compounds are yet to be identified, T. ferdinandiana fruit has been shown to contain benzoic acids, flavanols, or flavanones. ${ }^{[1]}$ T. ferdinandiana fruit is a good source of gallic acid [Figure 1b] and ellagic acid [Figure 1c], ${ }^{[6,26]}$, both of which demonstrate antioxidant and anticarcinogenic activity in vitro. ${ }^{[27,28]}$ Previous studies have also noted that $T$. ferdinandiana fruit is very rich in chlorophyll a [Figure 1e] and chlorophyll b [Figure 1f], which have previously been shown to be capable of relieving oxidative stress. ${ }^{[2]}$ Lipophilic T. ferdinandiana fruit extracts are also rich in lutein [Figure $1 \mathrm{~g}$ - a carotenoid antioxidant compound associated with eye health] and with vitamin E [Figure 1d] and vitamin E analogs. ${ }^{[1]}$ Hesperitin [Figure 1h], the glycosides kaempferol [Figure 1i] and luteolin [Figure 1j], and the glucoside quercetin [Figure 1k] are some of the other antioxidants present in $T$. ferdinandiana fruit. ${ }^{[1]} T$. ferdinandiana fruit is also a good source of the minerals magnesium, zinc, calcium, potassium, sodium, iron, phosphorous, manganese, copper, and molybdenum. ${ }^{[1]}$

T. ferdinandiana fruit antioxidants may reduce oxidative stress in several ways: directly, by reaction with aqueous peroxyl radicals by donating one or two electron, or indirectly, by restoring the antioxidant properties of fat-soluble vitamin E. Another major function is to keep glutathione (GSH), L-cysteine, and $\mathrm{N}$-acetyl-cysteine (antioxidants) in a reduced form, allowing them to continue their powerful free radical quenching effects. Another biochemical function for phytochemical antioxidants is to compete with free radicals to bind to the substrates. This function is specifically helpful in the formation of carcinogenic nitrosamines. ${ }^{[30]}$

\section{CELLULAR REDOX STATE AND CELL SURVIVAL}

As a result of oxidative metabolism for energy production, all aerobic cells generate reactive oxygen species (ROS) including superoxide radical $\left(\mathrm{O}_{2}{ }^{\bullet-}\right)$, hydrogen peroxide $\left(\mathrm{H}_{2} \mathrm{O}_{2}\right)$, free radicals, and hydroxyl radical $(\mathrm{OH} \bullet) \cdot{ }^{[31]}$ Free radicals are chemical species, which contain one or more unpaired electrons, making them highly unstable. These toxic products place cells under oxidative stress and can negatively affect their chances of survival. ${ }^{[32]}$ ROS are proficient at penetrating cells rapidly and reacting with intracellular metal ions ( $\mathrm{Fe}$ or $\mathrm{Cu}$ ) to generate highly reactive hydroxyl radicals that target cellular components (specifically DNA, lipids, and proteins) causing oxidative insults. ${ }^{[33]}$ They cause damage to other molecules by extracting electrons in order to attain stability themselves. ${ }^{[33]}$ ROS form a threat from within which may destabilize the cell's natural antioxidant systems resulting in damage to all biological macromolecules (nucleic acids, proteins, carbohydrates, and lipids). ${ }^{[34]}$ For example, $\mathrm{OH} \bullet$ is known to initiate lipid peroxidation which may result in the loss of membrane integrity and the generation of toxic aldehydes. ${ }^{[35]}$

Cells have developed a variety of mechanisms to minimize the effects of ROS. These defenses consist of both enzymatic and nonenzymatic mechanisms. ${ }^{[32]}$ The important antioxidant enzymes include superoxide dismutase (SOD), catalase, thioredoxin (THX), thioredoxin reductase, glutathione peroxidase (GPx), and glutathione reductase (GR). The nonenzymatic antioxidant defenses include GSH as well as vitamins $\mathrm{A}, \mathrm{C}$, and $\mathrm{E}$. When the prooxidative forces overwhelm the antioxidant defenses, oxidative stress is established. 


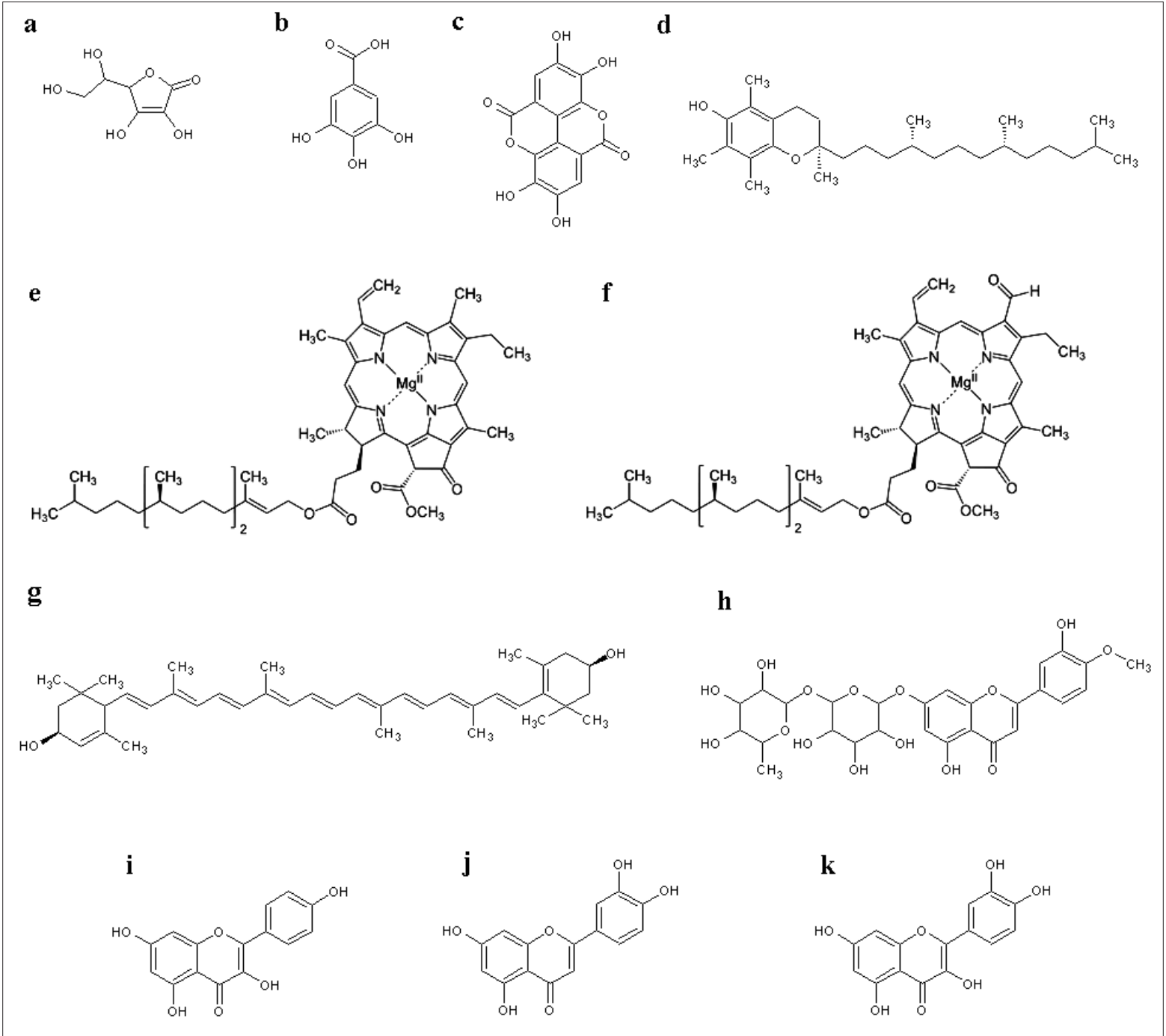

Figure 1: Chemical structures of molecules with antioxidant potential identified in T. ferdinandiana: (a) ascorbic acid (vitamin C), (b) gallic acid, (c) ellagic acid, (d) $\alpha$-tocopherol (vitamin E), (e) chlorophyll a, (f) chlorophyll b, (g) lutein, (h) hesperitin, (i) kaempferol, (j) luteolin, and (k) quercetin

Oxidative stress can induce cell death via apoptosis, damage DNA, as well as causing cancer and other diseases including atherosclerosis, diabetes, cirrhosis, ${ }^{[35]}$ male infertility, ${ }^{[36]}$ autoimmune disease, ${ }^{[37]}$ lung cancer, chronic inflammation, atherosclerosis, and Alzheimer's disease. ${ }^{[35]}$ Although almost all organisms possess antioxidant defense and repair systems which have evolved to protect them against oxidative damage, these systems are insufficient to entirely prevent the damage. ${ }^{[38]}$ However, individuals with elevated dietary intakes of nonenzymatic antioxidants such as vitamins A, C, and $\mathrm{E}$ are less likely to suffer heart and vascular diseases, diabetes, and some forms of cancer. ${ }^{[39]}$ Therefore, antioxidants such as vitamin $\mathrm{C}$ and polyphenols like ellagic acid in T. ferdinandiana fruit could contribute to reducing oxidative damage via nonenzymatic mechanisms and the scavenging of free radicals. Studies into the medicinal effects of antioxidants have proved confusing, with some studies showing therapeutic effects ${ }^{[0,41]}$ while other studies indicate that these antioxidants may themselves be toxic. ${ }^{[42,43]}$ It has been shown in a variety of human and animal models that the effects of vitamin $\mathrm{E}$ and vitamin $\mathrm{C}$ are dose dependent with low doses behaving as antioxidants, while high doses themselves induce toxicity through oxidative stress. ${ }^{[42,44]}$

There is a growing interest in the use of natural antioxidants to protect against a variety of diseases. The consumption of beverages such as tea and fruit juices, which are rich in flavonoids, has been associated with the decline of serum cholesterol and systolic blood pressure, thus reducing coronary vascular diseases. ${ }^{[45]}$ The consumption of the Garcinia kola's seeds, which contains the potent antioxidant kolaviron, has been reported to have anticarcinogenic and hepatoprotective effects. ${ }^{[46]}$ In addition, high levels of antioxidant phytochemicals within cloves have been linked to the prevention of lung cancer. ${ }^{[47]}$ Even drinking wine is linked with protection against oxidative stress through its antioxidant phytochemicals. ${ }^{[45]}$ Therefore, antioxidant supplements, or foods containing high levels of antioxidants, may be useful in reducing oxidative related diseases and disorders. T. ferdinandiana fruit, with the highest recorded 
levels of antioxidants of any plant in the world, therefore has potential in decreasing cellular oxidative stress and treating a myriad of oxidative diseases and disorders. Despite this and the ethnobotanical usage of this plant, no evidence was found in the literature of $T$. ferdinandiana fruit being tested for any bioactivity other than its antioxidant activity. Recent studies in our lab show correlation of Kakadu plum and antibacterial activity. ${ }^{[48]}$

\section{Cellular signaling, control, and cancer formation}

The two major pathways involved in cell signaling are dependent on protein phosphorylation and the status of thiol group(s) in proteins under redox control of the cell. ${ }^{[49]}$ The thiol status is dependent on redox cascades triggered by oxidative and reductive stress experienced by the cell. Therefore, any changes in cellular redox environment affects signal transduction, DNA and RNA synthesis, protein synthesis, enzyme activation, regulation of cell cycle, ligand binding, DNA binding, and nuclear translocation. ${ }^{[50]}$ Studies indicate that transcription factors are active in their reduced form and their translocation to the nucleus is redox dependent. ${ }^{[51]}$ Furthermore, high concentrations of reduced thiols stimulate cellular proliferation (i.e., cellular growth and proliferation is consistent with a reducing environment). Conversely, an oxidizing environment initiates cell death where prooxidants increase levels of reactive oxygen species inducing apoptosis. ${ }^{[52,53]}$ Antioxidants such as GSH and thiol containing proteins (e.g. THX) may act as reducing agents and have been reported to prevent apoptosis. ${ }^{[54,55]}$ Ellagic acid (a known component of $T$. ferdinandiana fruit) has been shown to induce apoptosis in cancer cell lines as well as suppressing angiogenesis (the growth of new capillary blood vessels). ${ }^{[56]}$ Therefore, the redox environment may determine if a cell would proliferate, differentiate, or die. ${ }^{[57]}$

Regardless of the significance of redox-related cell signaling processes, the growth and development of normal cells is also regulated by additional growth promoting and inhibiting pathways. These pathways may be disrupted by genetic mutation; resulting in an aberration of cellular behavior. ${ }^{[58]}$ Proto-oncogenes and tumor suppressor genes are responsible for encoding proteins that regulate cell division/cycle and cell programed death by apoptosis and repair of damaged DNA. Mutations within specific genes have been implicated in the onset of cancer. ${ }^{[59]}$ These genes code seven vital classes of proteins:

- extracellular signaling molecules,

- signal receptors/intracellular receptors,

- signal transduction proteins/intracellular transducers,

- transcription factors,

- apoptotic proteins,

- cell cycle control proteins, and

- DNA repair proteins that are responsible for controlling cell growth and proliferation but it is the mutant forms that are cancerous. ${ }^{[59]}$

Hanahan and Weinberg ${ }^{[59]}$ have proposed that normal cells must acquire the following six phenotypes [Figure 2] to become malignant:
- $\quad$ Self-sufficiency in growth signals.

- Insensitivity to anti-growth signals.

- Limitless replicative potential.

- Tissue invasion and metastasis.

- $\quad$ Sustained angiogenesis.

- $\quad$ Evading apoptosis.

Hence cancer cells do not require external inducing signals to proliferate, and further fail to recognize signals that restrict cell division. In tumor genesis, multiple genes are altered and transmitted to daughter cells that are clones. These cells escape normal growth restraints and form a tumor, which may be benign or malignant. In the Hanahan and Weinberg model (summarized in Figure 2), chronological order of the six phenotypes and the mechanism by which these phenotypes are acquired may differ in each tumor. Genomic instability provides the driving force for acquiring new phenotypes.

Phytochemical studies of the nutritional value of $T$. ferdinandia have shown the fruits to be high in important polyphenolic antioxidants including ellagic and gallic acids. ${ }^{[26]}$ Pure ellagic and gallic acids and their derivatives have previously been shown to be antibacterial ${ }^{[60,61]}$ and to have cytotoxic activity toward cancer cells while being nontoxic to normal cell lines. ${ }^{[27,28]}$ While the mechanism is not completely understood, it is known that ellagic acid induces cellular detachment, decreased cell viability, and induced apoptosis as measured by DNA strand breaks. It also induced alterations in cell cycle arrest. ${ }^{[62]} \mathrm{A}$ better understanding of T. ferdinandia phytochemicals (including ellagic acid) and the cellular mechanisms involved could lead to the potential antitumorigenic treatment.

\section{Cellular proliferation and differentiation}

In a multicellular entity, cell proliferation requires high GSH

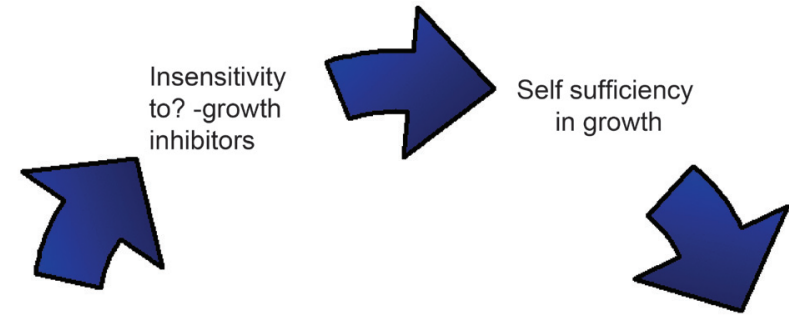

Tissue invasion \& $\mathrm{m}$ etastasis Phenotypes required for
malignancy Limitless replication capability

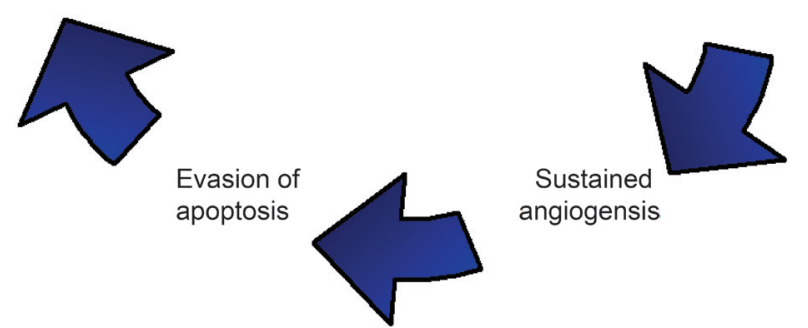

Figure 2: Hanahan and Weinberg model: defining six properties a tumor acquires. 
levels and low levels of antioxidant proteins such as SOD, GPx, and catalase, favoring a reducing environment. ${ }^{[63,64]}$ The redox environment of the cell has a significant role in cell proliferation. Sequential changes in antioxidant profiles suggest that GSH levels fluctuate in response to cell cycle progression. ${ }^{[65]}$ Low level of these antioxidants induces cell proliferation while high levels inhibit it. ${ }^{[6,67]}$ Therefore, proliferation favors a reducing environment while differentiation requires an oxidizing environment. ${ }^{[68,69]}$ Thus, ROS could also play a very important physiological role as secondary messengers ${ }^{[70]}$ and in maintenance of redox balance. Consumption of phenolic antioxidants in $T$. ferdinandia fruits could help to reduce the oxidative stress of the cell and the whole organism in total.

\section{Cell death}

Oxidizing environments may predispose a cell to apoptosis or necrosis depending on the oxidative stimuli provided. ${ }^{[71]}$ Moderate lethal oxidative stimuli cause apoptosis whereas severe oxidative stress leads to necrosis. Apoptosis requires ATP for organized cell death. The stages of apoptosis are:

- Initiation-signal is received.

- Effector phase-signal is integrated and cell fate is decided.

Irreversible execution phase-digestion of DNA and protein occurs. Furthermore severe oxidative stress depletes energy and damages the mitochondrial machinery [Figure 3].

\section{Regulated cell death (apoptosis)}

Apoptosis is a regulated cell death program that involves a mechanism of cell replacement, tissue remodeling, and subsequent removal of damaged cells. ${ }^{[72,73]}$ Apoptosis is characterized by cell shrinkage, chromatin condensation, internucleosomal DNA fragmentation, and formation of apoptotic bodies. ${ }^{[74,75]}$

Caspases are central to apoptosis and eliminating caspases through mutation or pharmacological inhibitors may slow down or block apoptosis. ${ }^{[7]}$ However, antioxidants from plants extracts such as $T$. ferdinandia may also have the potential to enhance apoptotic activity in cancer cells by inducing DNA strand breaks and cell detachments.

\section{INFLAMMATION, OXIDATIVE STRESS, AND CANCER}

Pathological diseases that share oxidative stress and affinity towards cancer (eg Fanconi anaemia, Xeroderma pigmentosum, Ataxia telangiectasia, Bloom Syndrome, Down Syndrome and cystic fibrosis) are congenital disorders, where cells display evidence of increased inflammation [Table 1]. The affected individuals show an increased incidence of cancer $^{[77]}$ and chromosome instability is also a common feature of the first four disorders in Table $1{ }^{[78]}$ This suggests that increased oxidative stress may contribute to development of genetic instability (ie. a mutant phenotype that is a hallmark of cancer cells).
The continuous production of oxidants at the site of chronic inflammation may induce cancer by excessive production of neutrophils, eosinophils and macrophages. Cancer is characterised by a reducing environment of the cell and can be considered as a disturbed balance between cell proliferation and cell death, shifted greatly towards cell proliferation. Anticancer agents such as antioxidants play a vital role in restoring the redox balance of cells. Redox balance in cancer cells is impaired in comparison to normal cells, which may be related to oncogenic stimulation [Figure 4]. Altered levels of antioxidant enzymes (SOD, catalase, glutathione peroxidase) and non-enzymatic antioxidants (GSH, Vitamin C, thioredoxin) along with changes in the related signal pathways, are evident in many human cancers. ${ }^{[89]}$ Detailed studies into the phenolic phytochemical components of the T.ferdinandiana could provide solutions to many medical problems.

\section{Therapeutic approach to cancer}

Currently used anti-cancer agents (eg. doxorubicin, daunorubicin, mitomycin $\mathrm{C}$, etoposide, cisplatin, arsenic trioxide, ionising radiation, photodynamic therapy) depend at least partially on the production of ROS for cytotoxicity. Sensitivity of tumour cells to oxidative stress and/or apoptosis may affect treatment success (Davis, 2001). Studies indicate that WEH17.2 mouse thymoma cells over expressing catalase (CAT38) or thioredoxin (THX) are resistant to glucocorticoid-induced apoptosis in vitro. This suggests that glucocorticoid-induced apoptosis occurs by a ROS dependant/independent mechanism. Average tumour weights increased in SCID mouse tumour xenografts

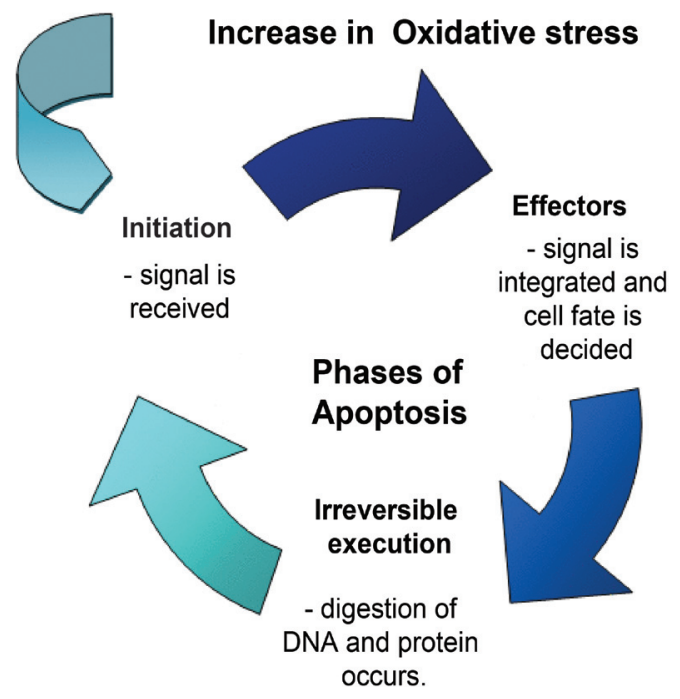

Figure 3: Phases of apoptosis

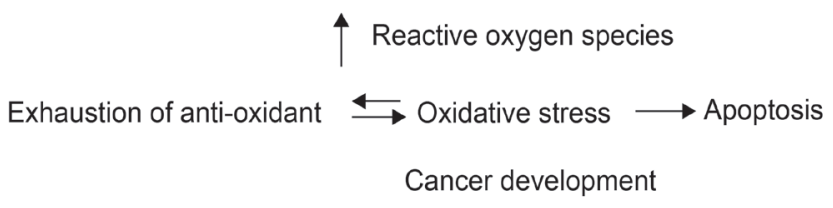

Figure 4: General overview of reactive oxygen species and effect on the cellular mechanism. 


\begin{tabular}{|c|c|c|c|}
\hline Cancer type & Etiological agent & Inflammatory condition & Reference \\
\hline Bladder & $\begin{array}{l}\text { Gram negative pathogens; } \\
\text { schistosomiasis; carcinogens }\end{array}$ & Eosinophillic cystitis, schistosomasis & [79] \\
\hline Cervical & HPV & Cervical inflammation & [80] \\
\hline $\begin{array}{l}\text { Gastric, Mucosa-associated lymphoid } \\
\text { tissue (MALT) }\end{array}$ & Helicobacter pylori & Gastritis & [81] \\
\hline Mesothelioma & Asbestos fiber exposure & Asbestosis & [82] \\
\hline Liver/ hepatocellular carcinoma & Hepatitis $B / C$ virus & Hepatitis/cirrhosis & [83] \\
\hline Lung & Tobacco smokes; nitosamines & Asthma, Chronic Bronchitis, Emphysema & [84] \\
\hline Lymphoma & HIV, and Herpes B virus & Not applicable & [85] \\
\hline Oesophago-gastric junction carcinoma & Smokes & Barrett's oesophagus & [86] \\
\hline Ovarian & $\begin{array}{l}\text { Asbestos exposure, endometriosis, } \\
\text { pelvic inflammatory diseases }\end{array}$ & Ovarian Epithelial Inflammation & {$[87]$} \\
\hline Pancretic & Tobacco and alcoholism & Pancreatis & [88] \\
\hline
\end{tabular}

from cells over-expressing catalase or thioredoxin. Tumours from both transfectants contained fewer apoptotic cells but mitotic cell numbers were similar. This suggests that antioxidant over-expression results in increased tumour size due to a decrease in apoptosis. ${ }^{[78]}$ In contrast, the effects of the ellagic acid, inhibiting the growth of the cervical carcinoma ${ }^{[00]}$ and neuroblastoma cells ${ }^{[62]}$ are dose dependent. Reducing antioxidant levels increases cancer cell viability. In summary, carcinogenesis resulting from inflammation induced by oxidative stress leads to genetic instability that causes the emergence of new tumour phenotypes. In such populations, decrease in apoptosis, increase in tumour growth and subsequent tumour progression are observable. ${ }^{[62,90]}$ Ellagic acid induces detachment, proliferation inhibition, apoptosis and cell cycle alterations in cancer and neuroblastoma cell lines in vitro. ${ }^{[62]}$ Therefore extracts containing ellagic acid (such as T. ferdinandia fruit extracts) have potential as chemotherapeutic agents for cancer treatment/prevention.

\section{CONCLUSION}

Cancer is a major public health burden, both in developed and developing countries. Plant derived agents such as taxol, vinblastine, vincristine, and the camptothecin derivatives topotecan and irinotecan and etoposide (derived from epipodophyllotoxin) are in clinical use globally ${ }^{[1]}$ for the treatment of cancer. With regard to previous phytochemical studies, ${ }^{[11,12]}$ it is surprising that the chemotherapeutic potential of T. ferdinandiana remains largely unexamined. Although T. ferdinandiana fruit extracts are not yet fully characterised due to difficulties in separating some components, high levels of antioxidant molecules have been reported. Apart from the high ascorbic, gallic and ellagic acid levels previously discussed, T. ferdinandiana fruit also contains high levels of other phenolic compounds which have therapeutic potential that is not just limited to cancer treatment. Polar T. ferdinandiana fruit extracts contains nearly 5 fold higher levels of antioxidants than in blueberries. ${ }^{[11]}$ Most of the studies regarding this plant report solely on the vitamin $\mathrm{C}$ level and the total antioxidant capacity without, examining medicinally important bioactivities. The current review highlights the chemotherapeutic potential of the phytochemicals of T. ferdinandiana. In particular, this manuscript describes the potential of this plant in treatment for disorders related to cellular redox control (eg cellular proliferation, inflammation, cancer, diabetes, obesity, cardiovascular and neurodegenerative diseases).

\section{REFERENCES}

1. Newman DJ, Cragg GM, Snader KM. Natural products as sources of new drugs over the period 1981-2002. J Nat Prod 2003;66:1022-37.

2. Newman DJ, Cragg GM. Natural products as sources of new drugs over the last 25 years. J Nat Prod 2007;70:461-77.

3. Hegarty MP, Hegarty EE. Food safety of Australian Plant Bushfoods. Rural Ind Res Dev Corp 2001;1:34-5.

4. Pedley L. Combretaceae. Flora Aust 1995;18:255-93.

5. Brock J. Top End Native plants: A Comprehensive Guide to the Trees and Shrubs of the Top End of the Northern Territory. Sydney, Australia: Reed Books; 2001.

6. Cunningham AB, Garnett S, Gorman J, Courtenay K, Boehme D. Eco-Enterprises and Terminalia ferdinandiana: "Best Laid Plans" and Australian Policy Lessons. Econ Bot 2009;63:16-28.

7. Byrnes NB. A Revision of the Combretaceae in Australia. Queensland Herbarium, Brisbane, Australia; 1977.

8. Wheeler JR. Family 81 Combretaceae. In: Wheeler JR, editor. Flora of the Kimberley Region. Department of Conservation and Land Management, Como, Australia; 1992. p. 551-9.

9. Dunlop CR, Leach GJ, Cowie ID. Acacia. In Flora of the Darwin Region. Conservation Commission of the Northern Territory Botanical Bulletin 1995;20:1-21.

10. Gorman JT, Griffith AD, Whitehead PJ. An Analysis of the use of Plant Products for Commerce in Remote Aboriginal Communities of Northern Australia. Econ Bot 2006;60:362-73.

11. Konczak I, Zabaras D, Dunstan M, Aguas. Antioxidant capacity and hydrophilic phytochemicals in commercially grown Australian fruits. Food Chem 2010;123:1048-54.

12. Netzel M, Netzel G, Tian Q, Schwartz S, Konczak I. Native Australian fruits - a novel source of antioxidants for food. Innov Food Sci Emerg Technol 2007;8:339-46.

13. Potter JD. Cancer prevention: Epidemiology and experiment. Cancer Lett 1997;114:7-9.

14. Hertog MG, Bueno-de-Mesquita HB, Fehily AM, Sweetnam 
PM, Elwood PC, Kromhout D. Fruit and vegetable consumption and cancer mortality in the caerphilly study. Cancer Epidemiol Biomarkers Prev 1996;5:673-7.

15. Vita JA. Polyphenols and cardiovascular disease: Effects on endothelial and platelet function. Am $\mathrm{J}$ Clin Nutr 2005;81:292S-7S.

16. Youdim KA, Spencer JP, Schroeter H, Rice-Evans CA. Dietary flavonoids as potential neuroprotectans. Biol Chem 2002;383:503-19.

17. Tsuda T, Horio F, Uchida K, Aoki H, Osawa T. Dietary cyanidin 3-O-b- D-glucoside-rich purple corn colour prevents obesity and ameliorates hyperglycemia in mice. J. Nutr 2003;133:2125-30.

18. Rice-Evans C, Miller N, Paganga. Antioxidant properties of phenolic compound. Trends Plant Sci 1997;2:152-9.

19. Moskaug JO, Carlsen $\mathrm{H}$, Myhrstad MC, Blomhoff $\mathrm{R}$. Polyphenols and glutathione synthesis regulation. Am J Clin Nutr 2005;81:277-83S

20. Moshi MJ, Mbwambo ZH. Some pharmacological properties of extracts $f$ Terminalia sericea roots. J Ethnopharmacol 2005;97:43-7.

21. Fan $\mathrm{YM}, \mathrm{Xu} \mathrm{LZ}$, Gao J, Wang $\mathrm{Y}$, Tang $\mathrm{XH}$, Zhao $\mathrm{XN}$, et al. Phytochemical and anti-inflammatory studies on Terminalia catappa. Fitoterapia 2004;75:253-60.

22. Dwivedi S. Terminalia arjuna Wight \& Arn - A useful drug for cardiovascular disorders. J Ethnopharmacol 2007;114:114-29.

23. Miller JB, James KW, Maggiore PM. Tables of composition of Australian Aboriginal foods. Aboriginal Studies Press, 1993; 256.

24. Woods B. A study of the intra-specific variations and commercial potenatial of Terminalia fredinandiana (the kakadu Plum). MSc thesis, Northern Territory University, Australia, 1995.

25. Johnson PD. Acerola (Malpighia glabra L., M. punicifolia L., M. emarginata D.C.): agriculture, production and nutrition. World Rev Nutr Diet 2003;91:67-75.

26. Cherikoff V, Kowalski G. Superfoods for Superhealth. Discover the Wonders of Australian Native Fruits. 2008 [Last cited on 2010 Oct 07]. Available from: http://www.kakadujuice.com/clientinc/ upload/Promotional.Tools/SuperFoods\%20Excerpt.pdf.

27. Losso JN, Bansode RR, Trappey A, Bawadi HA, Truax R. In vitro anti-proliferative activities of ellagic acid. J Nutr Biochem 2004;15:672-78.

28. Ohno Y, Fukuda K, Takemura G, Toyota M, Watanabe M, Yasuda $\mathrm{N}$, et al. Induction of apoptosis by gallic acid in lung cancer cells. Anticancer Drugs 1999;10:845-51.

29. Motilva MJ. Chlorophylls - from functionality in food to health relevance. In: Heinonen $M$, editor. 5th Pigments in Food Congress - for quality \& health, Proceedings of the 5th International Congress on Pigments in Food; Helsinki, Finland: 2008. p. 69-73.

30. Moser U, Bendich A. Vitamin C. In: Machlin LJ, editor. Handbook of vitamin C. $1^{\text {st }}$ ed. Marcel Dekker: New York; 1991.

31. Barzilai A, Yamamoto KI. DNA damage responses to oxidative stress. DNA Repair 2004;3:1109-15.

32. Poli G, Leonarduzzi G, Biasi F, Chiarpotto E. Oxidative stress and cell signaling. Curr Med Chem 2004;11:1163-82.

33. Valko M, Izakovic M, Mazur M, Rhodes CJ, Telser J. Role of oxygen radicals in DNA damage and cancer incidence. Mol Cell Biochem 2004;266:37-56.

34. Finkel T, Holbrook NJ. Oxidants, oxidative stress and the biology of the aging. Nature 2000;408:239-47.

35. Halliwell B, Gutteridge MC. Free radicals in biology and medicine, 3rd ed. Oxford: Oxford University Press; 1999.

36. Saleh RA, Agarwal A. Oxidative Stress and Male Infertility: From Research Bench to Clinical Practice. J Androl 2002;23:737-52.
37. Kumagai S, Nobuhara $Y$, Saegusa J. Oxidative stress and autoimmune diseases. Nippon Naika Gakkai Zasshi 2003;92:1096-103.

38. Simic GM. Mechanisms of inhibition of free-radical processed in mutagenesis and carcinogenesis. Mutat Res 1988;202:377-86.

39. Gey KF. Cardiovascular disease and vitamins: Concurrent correction of 'suboptimal' plasma antioxidant levels may, as an important part of the 'optimal' nutrition, help to prevent early stages of cardiovascular disease and cancer, respectively. Bib Nutr Dieta 1995;52:75-91.

40. Tafazoli S, Wright JS, O'Brien PJ. Proxidant and antioxidant activity of vitamin $\mathrm{E}$ analogues and troglitazone. Chem Res Toxicol 2005;18:1567-74.

41. Coşkun Ş, Gönül B, Güzel NA, Balabanli B. The effects of vitamin $\mathrm{C}$ supplementation on oxidative stress and antioxidant content in the brains of chronically exercised rats. Mol Cell Biochem 2005;280:135-8.

42. Sirdaarta J, Cock IE. Vitamin E and Trolox ${ }^{\mathrm{TM}}$ reduce toxicity of Aloe barbadensis Miller juice in Artemia franciscana nauplii but individually are toxic at high concentrations. Internet $\mathrm{J}$ Toxicol 2008;5(1)

43. Driver C, Georgeou A. Variable effects of vitamin E on Drosophilia longevity. Biogerontol 2003;4:91-5.

44. Miller ER, Pastor-Barriuso R, Dalal D, Riemersma RA. Metaanalysis: High dosage vitamin $\mathrm{E}$ supplementation may increase all-cause mortality. Ann Intern Med 2005;142:37-46.

45. Pearson DA, Tan CH, German JB, Davis PA, Gershwin ME. Apple juice inhibits low density lipoprotein oxidation. Life Sci 1999;64:1913-20.

46. Farombi EO, Adepoju BF, Ola-Davies OE, Emerole GO Chemoprotection of aflatoxin B1-induced genotoxicity and hepatic oxidative damage in rats by kolaviron, an natural biflavinoid of Garcinia kola seeds. Eur J Cancer Prev 2005;14:3,207-14.

47. Banerjee S, Panda CK, Das S. Clove (Syzgium aromaticum L.), a chemopreventitive agent for lung cancer. Carcinogenesis 2006;27:1645-54.

48. Cock IE, Mohanty S. Evaluation of the antibacterial activity and toxicity of Terminalia ferdinandia fruit extracts. Pharmacogn Mag Forthcoming 2011.

49. Klatt $P$, Lamas $S$. Regulation of protein function by Sglutathiolation in response to oxidative and nitrosative stress. Eur J Biochem 2000;267:4928-44.

50. Makino Y, Yoshikawa N, Okamoto K, Hirota K, Yodoi J, Makino I, et al. Direct association with thioredoxin allows redox regulation of glucocorticoid receptor function. J Biol Chem 1999;274:3182-8.

51. Okamoto K, Tanaka H, Ogawa H, Makino Y, Eguchi H, Hayashi $\mathrm{S}$, et al. Redox-dependent regulation of nuclear import of the glucocorticoid receptor. J Biol Chem 1999;274:10363-71.

52. Hamilos DL, Zelarney P, Mascali JJ. Lymphocyte proliferation in glutathione-depleted lymphocytes: Direct relationship between glutathione availability and the proliferative response. Immunopharmacology 1989;18:223-35.

53. Kim HS, Lee JH, Kim IK. Intracellular glutathione level modulates the induction of apoptosis by delta 12-prostaglandin J2. Prostaglandins 1996;51:413-25.

54. Gabby M, Tauber M, Porat S, Simantov R. Selective role of glutathione in protecting human neuronal cells from dopamine induced apoptosis. Neuropharmacology 1996;35:571-8.

55. Iwata S, Hori T, Sato N, Hirota K, Sasada T, Mitsui A, et al. Adult $T$ cell leukemia (ATL)-derived factor/human thioredoxin prevents apoptosis of lymphoid cells induced by L-cystine and glutathione depletion: Possible involvement of thiol-mediated redox regulation in apoptosis caused by pro-oxidant state. $J$ 
Immunol 1997;158:3108-17.

56. Kim S, Gaber MW, Zawaski JA, Zhang F, Richardson M, Zhang $\mathrm{XA}$, et al. The inhibition of glioma growth in vitro and in vivo by a chitosan/ellagic acid composite biomaterial. Biomaterials 2009;30:4743-51.

57. Cai J, Jones DP. Superoxide in apoptosis: Mitochondrial generation triggered by cytochrome c loss. J Biol Chem 1998;273:11401-4.

58. Lodish H, Berk A, Matsudaira P, Kaiser CA, Kreiger M, Scott MP, et al. Molecular Cell Biology. $5^{\text {th }}$ ed. New York: W.H. Freeman and Company; 2004.

59. Hanahan D,Weinberg RA. The hallmarks of cancer. Cell 2000;100:57-70.

60. Hancock V, Dahl M, Munk Vejborg R, Klemm P. Dietary plant components ellagic acid and tannic acid inhibit Escherichia coli biofilm formation. J Med Microbiol 2010;59:496-8.

61. Naz S, Siddiqi R, Ahmad S, Rasool SA, Sayeed SA. Antibacterial activity directed isolation of compounds from Punica granatum. J Food Sci 2007;72:341-5.

62. Fjaeraa $\mathrm{C}$, Nanberg $\mathrm{E}$. Effect of ellagic acid on proliferation, cell adhesion and apoptosis in SH-SY5Y human neuroblastoma cells. Biomed Pharmacother 2009;63:254-61.

63. Allen RG, Venkatraj VS. Oxidants and antioxidants in development and differentiation. J Nutr 1992;122:631-5.

64. Sohal RS, Allen RG. Oxidative stress as a causal factor in differentiation and aging: A unifying hypothesis. Exp Gerontol 1990;25:499-522.

65. Schafer FQ, Buettner GR. Redox environment of the cell as viewed through redox state of the glutathione disulphide/ glutathione couple. Free Radic Biol Med 2001;30;1191-212.

66. Brown MR, Miller FJ, Li WG, Ellingson AN, Mozena JD, Chatterjee $\mathrm{P}$, et al. Overexpression of human catalase inhibits proliferation and promotes apoptosis in vascular smooth muscle cells. Circ Res 1999;85:524-33.

67. Yang M, Nazhat NB, Jiang X, Kelsey SM, Blake DR, Newland AC, et al. Adriamycin stimulates proliferation of human lymphoblastic leukaemic cells via a mechanism of hydrogen peroxide $(\mathrm{H} 2 \mathrm{O} 2)$ production. Br J Haematol 1996;95:339-44.

68. Burdon $\mathrm{RH}$. Superoxide and hydrogen peroxide in relation to mammalian cell proliferation. Free Radic Biol Med 1995;18:775-94.

69. Alaluf S, Muir-Howie H, Hu HL, Evans A, Green MR. Atmospheric oxygen accelerates the induction of a post-mitotic phenotype in human dermal fibroblasts: The key protective role of glutathione. Differentiation 2000;66:147-55.

70. Lowenstein CJ, Dinerman JL, Snyder SH. Nitric-oxide - a physiological messenger. Ann Intern Med 1994;120:227-37.

71. Chandra J, Samali A, Orrenius S. Triggering and modulation of apoptosis by oxidative stress. Free Radic Biol Med 2000;29:323-33.

72. Haslett C. Resolution of acute inflammation and the role of apoptosis in the tissue fate of granulocytes. Clin Sci 1992;83:639-48.

73. DeLong MJ. Apoptosis: A modulator of cellular homeostasis and disease states. Ann N Y Acad Sci 1998;842:82-90.

74. Wyllie AH, Kerr JF, Currie AR. Cell death: The significance of apoptosis. Int Rev Cytol 1980;68:251-306.

75. McConkey DJ, Hartzell P, Nicotera P, Wyllie AH, Orrenius S. Stimulation of endogenous endonuclease activity in hepatocytes exposed to oxidative stress. Toxicol Lett 1988;42:123-30.
76. Ashkenazi A, Dixit VM. Death receptors: Signalling and modulation. Science 1998;281:1305-8.

77. Pagano G, Korkina LG, Brunk UT, Chessa L, Degan P, delPrincipe $\mathrm{D}$, et al. Congenital disorders sharing oxidative stress and cancer proneness as phenotypic hallmarks: Prospects for joint research in pharmacology. Med Hypotheses 1998;51:253-66.

78. Tome ME, Baker AF, Powis G, Payne CM, Briehl MM. Catalaseoverexpressing thymocytes are resistant to glucocorticoidinduced apoptosis and exhibit increased net tumor growth. Cancer Res 2001;61:2766-73.

79. Michaud DS. Chronic inflammation and bladder cancer. Urol Oncol 2007;25:260-8.

80. Castle PE, Hillier SL, Rabe LK, Hildesheim A, Herrero R, Bratti MC. An association of Cervical Inflammation with High -Grade Cervical Neoplasia in women infected with Oncogenic Human Papillomavirus (HPV). Cancer Epidemiol Biomarkers Prev 2001;10:1021-7.

81. Frenkel K, Wei L, Wei H. 7,12-Dimethylbenz[a]anthracene induces oxidative DNA modification in vivo. Free Radic Biol Med 1995; 19:373-80.

82. Boorstein RJ, Teebor GW. Mutagenicity of 5-hydroxymethyl2'-deoxyuridine to Chinese hamster cells. Cancer Res 1988;48:5466-70.

83. Frenkel K, Chrzan K. "Radiation-like modification of DNA and $\mathrm{H} 2 \mathrm{O} 2$ formation by activated polymorphonuclear leukocytes (PMNs)", In: Cerutti P, Nygaard OF, Simic M, editors. Anticarcinogenesis and Radiation Protection. New York: Plenum Publishing Corp; 1987. p. 97-102.

84. Piipari R, Jaakkola JJ, Jaakkola N, Jaakkola MS. Smoking and asthma in adults. Eur Respir J 2004;24:734-9.

85. Nador GR, Cesarman E, Chadburn A, Dawson BD, Ansari QM, Said J, et al. Primary effusion lymphoma: A distinct clinicopathologic entity associated with the Kaposi's sarcomaassociated herpes virus. Blood 1996;88:645-56.

86. Barrett MT, Sanchez CA, Prevo LJ, Wong DJ, Galipeau PC, Paulson TG, et al. Evolution of neoplastic cell lineages in Barrett oesophagus. Nat Genet 1999;22:106-9.

87. Ness RB, Cottreau C. Possible role of Ovarian Epithelium Inflammation in Ovarian Cancer. J Natl Cancer Inst 1999;91:1459-67.

88. Karlson BM, Ekbom A, Josefsson S, McLaughlin JK, Fraumeni JF Jr, Nyrén O. The risk of Pancreatic Cancer following Pancreatitis: An association due to confounding? Gastroenterology 1997;113:587-92.

89. McEligot AJ, Yang S, Meyskens FL Jr. Redox regulation by intrinsic species and extrinsic nutrients in normal and cancer cells. Annu Rev Nutr 2005;25:261-95.

90. Narayanan BA, Geoffroy O, Willingham MC, Re GG, Nixon DW. p53/p21 (WAF1/CIP1) expression and its possible role in G1 arrest and apoptosis in ellagic acid treated cancer cells. Cancer Lett 1999;136:215-21.

91. Mohammad Shoeb. Anticancer agents from medicinal plants. Bangladesh J Pharmacol 2006;1:35-41.

How to cite this Article: Mohanty S, Cock IE. The chemotherapeutic potential of Terminalia ferdinandiana: Phytochemistry and bioactivity. Phcog Rev 2012;6:29-36.

Source of Support: Nil, Conflict of Interest: None declared 